\title{
Jenis dan Teknik Pengemasan Terhadap Kualitas Bakso Aci dengan Penyimpanan Suhu Dingin
}

\author{
Deli Silvia*, Adinda Prila Dewi, Zulkarnain \\ Program Studi Teknologi Industri Cetak Kemasan, Jurusan Teknik Grafika dan Penerbitan, Politeknik Negeri Jakarta \\ Jl. Prof DR. G.A. Siwabessy, Kukusan Beji, Depok 16424 Indonesia \\ Email: deli.silvia@grafika.pnj.ac.id
}

\begin{abstract}
Abstrak
Telah dilakukan penelitian tentang pengaruh jenis material kemasan vakum dan non-vakum terhadap kualitas kadar air, dan organoleptik bakso aci pada penyimpanan suhu dingin. Tujuan Penelitian ini untuk mengetahui pengaruh kemasan bakso aci dengan penggunaan plastik Polietilen (PE) dan plastik nilon yang dikemas melalui teknik pengemasan vakum dan non-vakum pada penyimpanan suhu dingin. Serta untuk mendapatkan jenis kemasan yang tepat dalam penggunaannya terhadap kualitas bakso aci. Pengujian yang dilakukan meliputi uji kadar air dan uji organoleptik. Metode analisa statistik yang digunakan berupa Rancangan Acak Lengkap (RAL) untuk mendapatkan hasil yang lebih baik dan tidak terjadi kesalahan yang signifikan. Penelitian yang dilakukan menggunakan RAL dengan 4 perlakuan dan 2 kali pengulangan. Pengolahan data yang dilakukan dengan software SPSS (Statistical Product and Service Solutions) menggunakan metode ANOVA ( Analysis of Variance) dan uji lanjut Duncan untuk Uji kadar air dan menggunakan Kruskall Walls dan uji lanjut dengan Mann- Whitney untuk uji organoleptik terhadap kenampakan, aroma dan tekstur. Pengujian organoleptik mengikuti standar SNI untuk Bakso dengan 10 orang panelis tak terlatih. Berdasarkan penelitian yang dilakukan didapatkan hasil bahwa kadar air terendah yaitu dengan penggunaan kemasan polietilen (PE) teknik pengemasan Vakum dengan nilai 2,35. Hasil untuk pengujian Organoleptik, yang dapat disimpulkan dari segi kenampakan, aroma dan tekstur perlakuan yang terbaik adalah dengan penggunaan jenis kemasan polietilen, dengan teknik pengemasan vakum dan jenis kemasan nilon dengan teknik pengemasan vakum yang mampu meyimpan dengan baik hingga hari ke-8.
\end{abstract}

Kata Kunci : kemasan, vakum, non-vakum, polietilen, nilon, organoleptik

\section{Abstract}

\section{Types and Packaging Techniques on the Quality of Tapioca meatballs with Cold Storage}

Research has been carried out on the effect of vacuum and non-vacuum packaging materials on the quality of water content and organoleptic properties of tapioca meatballs in cold storage. The purpose of this study was to determine the effect of meatball tapioca packaging with the use of polyethylene (PE) plastic and Nilon plastic packaged through vacuum and non-vacuum packaging in cold storage. As well as to get the right type of packaging in its use on the quality of tapioca meatballs. The tests carried out included water content tests and organoleptic tests. The statistical analysis method used was a completely randomized design (CRD) to get better results and there were no significant errors. The study was conducted using RAL with 4 treatments and 2 treatments. Data processing was carried out using SPSS (Statistical Product and Service Solutions) software using the ANOVA (Analysis of Variance) method and Duncan's further test for moisture content testing and using Kruskall Walls and further testing with Mann-Whitney for organoleptic tests on appearance, aroma and texture. The organoleptic followed the SNI standard for Meatballs with 10 panelists not being tested. Based on the research conducted, it was found that the lowest water content was the use of polyethylene (PE) packaging with a vacuum packaging technique with a value of 2.35. The results for organoleptic testing, which can be guaranteed in terms 
of appearance, smell and treatment are the best by using polyethylene packaging, with packaging techniques and Nilon packaging types with vacuum packaging techniques which are able to store well until the 8th day.

Keywords: packaging, vakum, non-vacuum, polyethylene, Nilon, organoleptic

\section{PENDAHULUAN}

Bakso merupakan jenis makanan yang cukup populer di Indonesia. Bakso memiliki aneka ragam jenis yang berbeda seperti bakso sapi, bakso ayam dan bakso aci. Permintaan konsumen yang meningkat terhadap bakso Aci berawal dari media sosial dan promosi antar teman sehingga banyak masyarakat yang penasaran kepada bakso Aci (Tripariyanto et al., 2021).

Proses pembuatan bakso biasanya dibutuhkan bahan pengisi yang memegang peranan penting dalam kualitas bakso. (Nuhriwangsa et al., 2021). Bahan pengisi atau pengikat memiliki fungsi untuk memperbaiki emulsi, memperbaiki rasa, juga mengurangi biaya produksi, dan sebagainya (Astuti dan Naufalin, 2012). Menurut Kartikawati dan Purnomo (2019), Bahan pengisi bakso yang biasa digunakan adalah tepung tapioka. Tepung tapioka digunakan untuk memperbaiki tekstur, menurunkan penyusuran, menaikkan daya ikat air, meningkatkan elastisitas dibutuhkan penambahan tepung (Nullah et al., 2016). Menurut Pramuditya, Galih \& Yuwono (2014), singkong memiliki kadaramilosa $21.43 \%$. Amilosa mampu mengikat air dengan mudah sehingga mampumempercepat peningkatan kadar air. Kandungan air pada bakso aci yang berlebihan mampu mempercepat pertumbuhan mikroorganisme sehingga bakso aci mudah mengalami kerusakan. Kandungan gizi bakso cocok dalam pertumbuhan mikroba, lantaran itu, bakso mempunyai masa simpan yang cukup pendek (Ismail et al., 2016). Menurut Park et al. (2021), Sebenarnya juga dapat menggunakan pati quino karena memiliki amilosa yang rendah), menurut Sujarwanta et al. (2021), dapat menggunakan dedak padi dan juga menurut Odiase et al. (2013), bahwa dapat menggunakan tepung kedelai. Namun, tepung tapioka merupakan salah satu tepung yang memiliki tingkat ketersediaan yang tinggi (Putra et al., 2011).

Kontak oksigen antara bakso aci dengan lingkungan mampu mempercepat proses kerusakan bakso aci. Jika kontak oksigen sedikit maka akan memperlambat proses kerusakan. Kandungan yang terdapat dalam bakso aci mampu meningkatkan proses terbentuknya mikroorganisme. Menurut Hamdani et al. (2017), selama penyimpanan, bakso dapat mengeluarkan air dari dalam gel kemudian perubahan aroma, rasa dan penurunan zat gizi akibat oksidasi lemak yang disebabkan kontak dengan oksigen. Menurut Nofreeana et al. (2017), pertumbuhan mikroorganisme seperti kapang/jamur dan bakteri dipengaruhi oleh faktor pengemasan. Pengemasan dengan menggunakan vakum dapat menghambat pertumbuhan bakteri aerob. Sehingga untuk mempertahankan kualitas bakso aci dibutuhkan jenis plastik dengan teknik pengemasan yang tepat. Jenis plastik yang digunakan harus memiliki permeabilitas uap air dan gas yang rendah.

Menurut Jayadi et al. (2016), Kemasan plastik polietilen yang mempunyai ketebalan 0,0001 sampai 0,01 inc, sebagai pengemas makanan, karena sifatnya yang thermoplastik, polietilen, dimana mudah dibuat kantung dengan derajat kerapatan yang baik. Menurut Maflahah dan Rahman (2016), kemasan polietilen dan Nilon memiliki karakteristik seperti permeabilitas rendah air rendah, kerapatan yang tinggi, mampu melindungi isi produk dan tahan terhadap berbagai suhu.

Dalam penelitian kali ini digunakan jenis plastik polietilen (PE) dan Nilon. Teknik pengemasan yang digunakan yaitu teknik pengemasan vakum dan non-vakum. Pengemasan vakum biasanya dikombinasikan karena sifatnya yang kuat, fleksibel, mudah dibentuk, serta sukar tembus air dan udara. Menurut Mulyawan et al. (2019), dalam penyimpanannya, jenis kemasan plastic dan suhu dingin yang mempengaruhi kualitas penyimpanan. Jika dilakukan penyimpanan dengan suhu kamar maka kerusakan makanan karena jumlah bakteri dapat meningkat hal ini disebabkan oleh mikroorganisme yang memanfaatkan bahan pangan tersebut untuk berkembang biak dan metabolisme, sehingga mampu mengalami perubahan pada rasa, aroma, 
tekstur hingga tidak dapat dikonsumsi kembali. (Candra et al., 2014)

Fokus penelitian ini menggunakan metode Rancangan Acak Lengkap (RAL) dengan suhu penyimpanan dingin. Diduga diantara olahan daging yang cepat mengalami kerusakan salah satunya adalah bakso aci. Sehingga pengujian kemasan vakum dengan PE dan Nilon ini menggunakan bakso aci. Penelitian dilakukan dengan tujuan untuk mempertahankan kualitas bakso aci.

\section{METODOLOGI}

Alat dan bahan yang digunakan adalah cawan porselen, oven merek Memert, desikator, neraca analitik merk Ohaus, piring, tusuk gigi, bahan yang digunakan adalah tepung terigu dan bahan lainnya untuk pembuatan bakso aci, kemasan PE dan Nilon.

Pada penelitian ini, metode yang digunakan adalah Rancangan Acak Lengkap (RAL) yang dilakukan pada penyimpanan suhu dingin. Rancangan Acak Lengkap (RAL) menggunakan 4 perlakuan dan 2 pengulangan. Empat perlakuan yang dilakukan adalah penggunaan jenis kemasan plastik polietilen dengan teknik vakum, jenis kemasan plastik polietilen dengan teknik nonvakum, jenis kemasan plastik nilon dengan teknik vakum dan jenis kemasan plastik nilon dengan teknik non-vakum. Tahapan penelitian yang dilakukan adalah sebagai berikut; Pembuatan bakso aci dengan resep yang sudah ada. Setelah didinginkan, masukan bakso aci kedalam kemasan yang sudah disediakan. Kemudian dilakukan pengujian kadar air menurut AOAC, (2005) dan Uji Organoleptik menurut SNI 01 2346-2006 (BSN, 2016).

Analisis kadar air (AOAC, 1995) dapat dilakukan dengan cara sebagai berikut; Cawan porselen disterilkan dalam oven selama 1 jam dengan suhu $100-105^{\circ} \mathrm{C}$, kemudian didinginkan di dalam desikator selama 15 menit dan ditimbang beratnya (A gram). Langkah kedua, Sampel ditimbang sebanyak 2 gram dan ditaruh dalam cawan porselen yang telah diketahui beratnya (B gram). Sampel dalam cawan porselen ini kemudian dikeringkan dalam oven pada suhu $100-105^{\circ} \mathrm{C}$ selama 4,5 jam, selanjutnya didinginkan di dalam desikator selama 15 menit dan ditimbang (C gram). Terakhir, pengeringan dilakukan kembali hingga mencapai berat konstan. Berat konstan didapatkan dengan memasukkan ke oven 1 jam pertama, didinginkan kemudian ditimbang, lalu dilakukan pengovenan kembali 1 jam setelah itu didinginkan kemudian ditimbang. Jika mengalami penurunan, maka dilakukann pengovenan kembali. Setelah itu didinginkan lalu ditimbang dan lakukan hingga tidak mengalami penurunan.

Uji organoleptik yang dilakukan berupa uji kesukaan atau uji hedonik (hedonic score scaling). Sifat mutu yang diuji merupakan warna, aroma, dan tekstur pada bakso aci potong, dimana sampel disediakan dalam wadah yang telah diberi kode.

\section{HASIL DAN PEMBAHASAN}

\section{Kadar Air}

Kadar air merupakan parameter pengujian yang penting pada produk dikarenakan kadar air merupakan komponen yang dapat mempengaruhi daya awet. (Wahyuni et al., 2021).

Hasil uji anova melalui tabel di atas menunjukkan pada hari ke-0, hari ke-2, hari ke-4 hari ke-6, dan hari ke-8 pada $p>0.05, H_{0}$ diterima sehingga tidak ada perbedaan nyata perlakuan kemasan PE vakum, PE non-vakum, Nilon vakum dan Nilon non-vakum terhadap bakso aci pada suhu dingin. Berdasarkan data penelitian pada table 4.1, dapat dilihat bahwa nilai kadar air pada penggunaan kemasan PE + Vakum mengalami peningkatan pada hari ke-2 dan hari ke- 6 dan mengalami penurunan kadar air pada hari ke-4 dan hari ke- 8. Kemasan PE + Non-Vakum mengalami peningkatan pada hari ke- 6 . Namun, mengalami penurunan kadar air pada hari ke-2, hari ke- 4 dan hari ke-8. Perlakuan dengan menggunakan kemasan Nilon + vakum mengalami peningkatan pada hari ke-4 dan hari ke- 6 . Namun pada hari ke2 dan hari ke-8 ia mengalami penurunan kadar air. Terakhir nilai kadar air pada penggunaan kemasan Nilon + non-vakum mengalami peningkatan pada hari ke-4 dan hari ke-6.

Pada Gambar 1, yang merupakan grafik pengaruh masa simpan dari dua jenis kemasan yaitu PE dan nilon dengan 2 teknik pengemasan ; vakum dan non-vakum dengan kadar air, terlihat bahwa jenis plastik polietilen vakum dan nonvakum serta jenis plastik Nilon vakum dan nonvakum memiliki penurunan kadar air pada hari ke8. Namun, penurunan yang paling kecil dihasilkan oleh kemasan polietilen vakum, dengan nilai 2,35. 
Tabel 1. Hasil kadar air

\begin{tabular}{lllll}
\hline \multirow{2}{*}{ Komponen } & \multicolumn{4}{c}{ Hasil Kadar air } \\
\cline { 2 - 5 } & F1 & F2 & F3 & F4 \\
\hline Hari ke 0 & $2.65 \pm 0.000^{\mathrm{a}}$ & $2.60 \pm 0.064^{\mathrm{a}}$ & $2,57 \pm 0.141^{\mathrm{a}}$ & $2.76 \pm 0.155^{\mathrm{a}}$ \\
Hari Ke 2 & $3.77 \pm 1.40^{\mathrm{a}}$ & $2.42 \pm 0.417^{\mathrm{a}}$ & $2.35 \pm 0.219^{\mathrm{a}}$ & $2.71 \pm 0.049^{\mathrm{a}}$ \\
Hari Ke 4 & $2.52 \pm 0.021^{\mathrm{a}}$ & $2.29 \pm 0.424^{\mathrm{a}}$ & $2.45 \pm 0.452^{\mathrm{a}}$ & $2.77 \pm 0.007^{\mathrm{a}}$ \\
Hari Ke 6 & $2.83 \pm 0.261^{\mathrm{a}}$ & $3.07 \pm 0.035^{\mathrm{a}}$ & $2.75 \pm 0.113^{\mathrm{a}}$ & $3.15 \pm 0.289^{\mathrm{a}}$ \\
Hari Ke 8 & $2.35 \pm 0.212^{\mathrm{a}}$ & $2.67 \pm 0.020^{\mathrm{a}}$ & $2.51 \pm 0.084^{\mathrm{a}}$ & $2.70 \pm 0.113^{\mathrm{a}}$ \\
\hline Keterangan : ${ }^{\text {a.b }}=$ notasi huruf serupa berarti tidak ada perbedaan nyata pada taraf uji Duncan pada $\alpha=0.05$
\end{tabular}

Keterangan : ${ }^{a . b}=$ notasi huruf serupa berarti tidak ada perbedaan nyata pada taraf uji Duncan pada $\alpha=0.05$

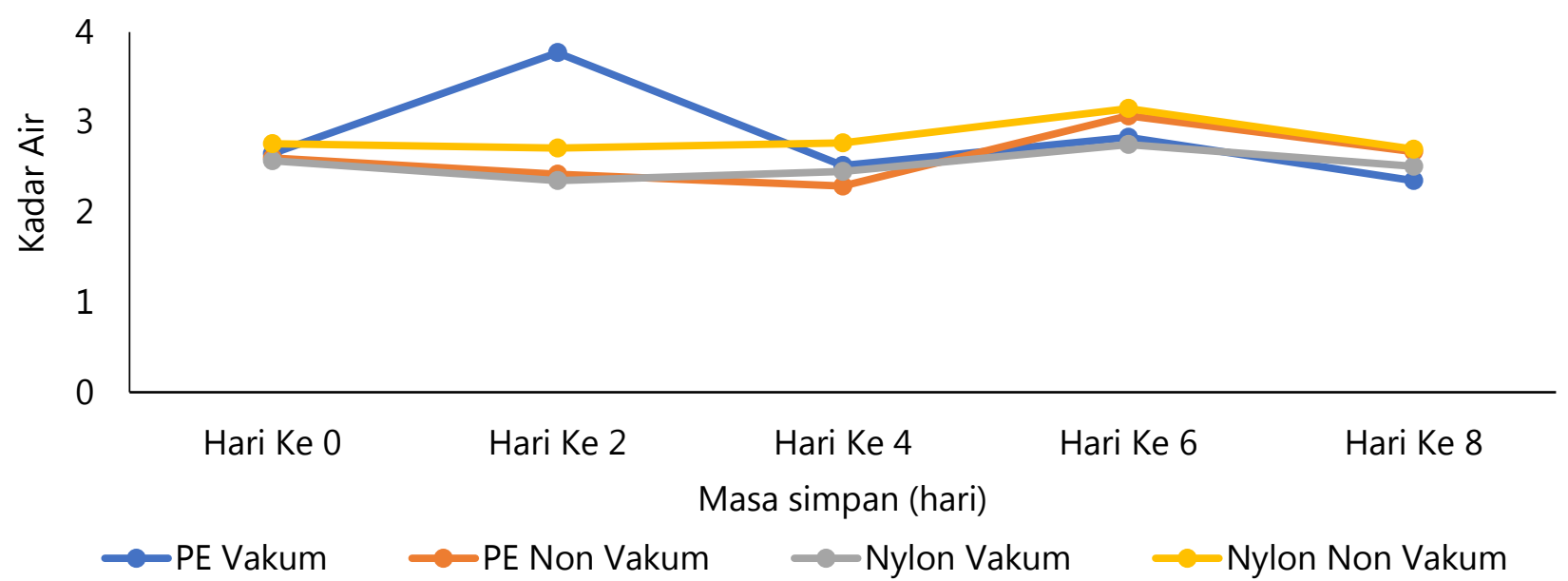

Gambar 1. Grafik pengaruh masa simpan jenis kemasan terhadap kadar Air

Menurut mulyawan., et al (2016), kemasan vakum berada dalam kondisi yang kedap dan hampa udara serta sangat padat sehingga menghambat penetrasi air ke dalam bahan dari lingkungan. Kemasan Nilon merupakan jenis kemasan yang cukup kedap terhadap gas. Penurunan kadar air juga disebabkan oleh adanya penyesuaian kadar air dalam dengan lingkungan penyimpanan bakso aci untuk mencapai kesetimbangan.

\section{Uji organoleptik}

Kenampakan pada bakso aci merupakan hal yang penting karena yang akan dilakukan konsumen sebelum membeli bakso aci adalah dengan melihat kenampakannya tersebut. Tabel 2, terlihat hasil Uji Kruskal Wallis parameter kenampakan menunjukkan $\mathrm{P}>0.05, \mathrm{H}_{0}$ diterima sehingga tidak ada perbedaan nyata antara perlakuan PE Vakum, PE Non-vakum, Nilon Vakum, Nilon Non-vakum terhadap kenampakan bakso aci yang disimpan pada hari ke-0 hingga hari ke-8.

Dari gambar 2, terlihat bahwa semakin lama penyimpanan maka nilai kenampakan pada daging mengalami penurunan. Pada gambar 2, ditunjukkan bahwa bakso aci yang dikemas dengan semua jenis kemasan dari hari ke-0 hingga hari ke8 dapat diterima oleh panelis. Namun teknik kemasan vakum lebih efektif dibandingkan teknik kemasan non- vakum. Menurut Nursafirah et al. (2021), penurunan kenampakan disebabkan oleh udara dan mikroorganisme.

Aroma dalam penilaian ilmu pangan merupakan indikator penting karena dapat memberikan hasil dengan cepat dalam penilaian diterima atau tidak nya suatu produk. Jika aroma tidak sedap maka minat konsumen akan hilang.

Pada Tabel 3, terlihat hasil Uji Kruskal Wallis untuk parameter aroma pada $\mathrm{P}<0.05$ di hari ke 4 dan hari ke $8, \mathrm{H}_{0}$ ditolak sehingga ada perbedaan nyata perlakuan antara PE Vakum, PE Non-vakum, Nilon Vakum, Nilon Non-vakum terhadap aroma. Kemudian, untuk melihat kelompok yang berbeda harus dilakukan uji Whitney. Pada hasil Uji Whitney ditemukan bahwa, tingkat kesukaan aroma bakso aci tidak berbeda nyata pada hari ke 0,2 dan 6 . Sedangkan mengalami perbedaan nyata $(P<0.05)$ 
pada hari ke 4 dan hari ke 8 pada PE Vakum, PE Non-vakum, Nilon Vakum, Nilon Non-vakum terhadap tingkat kesukaan aroma.

Dari Gambar 3, ditunjukkan bahwa penggunaan kemasan PE Vakum, PE Non-Vakum, Nilon Vakum, Nilon Non-Vakum mengalami penurunan tingkat kesukaan aroma dari hari ke-0 hingga hari ke-8.

Menurut Hendrawan et al. (2016), perlakuan kemasan memberikan nilai kesukaan yang berbeda pada panelis, hal ini disebabkan karena tingkat oksidasi berbeda berdasarkan permeabilitas kemasan sama halnya dengan perubahan bobot dan kadar air. Tekstur bakso aci merupakan hal yang harus di perhatikan karena pada saat pemasaran sebagai bentuk penilaian konsumen terhadap kualitas bakso aci.
Pada tabel 4 ditunjukkan bahwa huntuk asil Uji Kruskal Wallis parameter tekstur dengan tingkat perbedaan nyata $\mathrm{P}<0.05$ pada hari ke $8, \mathrm{H}_{0}$ ditolak sehingga ada perbedaan nyata perlakuan antara $\mathrm{PE}$ Vakum, PE Non-vakum, Nilon Vakum, Nilon Nonvakum terhadap tekstur. Untuk melihat kelompok yang berbeda dilakukan uji Whitney. Pada hasil Uji whitney ditemukan bahwa, tingkat kesukaan tekstur bakso aci tidak berbeda nyata pada hari ke $0,2,4$ dan 6. Sedangkan mengalami perbedaan nyata $(\mathrm{P}<0.05)$ pada hari ke 8 pada $\mathrm{PE}$ Vakum, $\mathrm{PE}$ Non-vakum, Nilon Vakum, Nilon Non-vakum terhadap tingkat kesukaan tekstur. Dari gambar 4, ditunjukkan bahwa perlakuan Nilon Vakum dapat menyimpan bakso aci hingga hari ke-8 dan masih diterima oleh konsumen.

Tabel 2. Hasil kenampakan organoleptic

\begin{tabular}{lllll}
\hline \multirow{2}{*}{ Komponen } & \multicolumn{4}{c}{ Hasil Organoleptik (Kenampakan) } \\
\cline { 2 - 5 } & F1 & F2 & F3 & F4 \\
\hline Hari ke 0 & $3.8 \pm 0.632^{\mathrm{a}}$ & $3.8 \pm 0.919^{\mathrm{a}}$ & $4.2 \pm 0.789^{\mathrm{a}}$ & $4.0 \pm 0.667^{\mathrm{a}}$ \\
Hari Ke 2 & $4.3 \pm 0.675^{\mathrm{a}}$ & $4.1 \pm 0.876^{\mathrm{a}}$ & $4.4 \pm 0.516^{\mathrm{a}}$ & $3.6 \pm 0.843^{\mathrm{a}}$ \\
Hari Ke 4 & $3.6 \pm 0.516^{\mathrm{a}}$ & $3.6 \pm 0.516^{\mathrm{a}}$ & $3.9 \pm 0.568^{\mathrm{a}}$ & $3.3 \pm 0.675^{\mathrm{a}}$ \\
Hari Ke 6 & $3.3 \pm 0.483^{\mathrm{a}}$ & $3.1 \pm 0.568^{\mathrm{a}}$ & $3.5 \pm 0.850^{\mathrm{a}}$ & $3.2 \pm 0.632^{\mathrm{a}}$ \\
Hari Ke 8 & $3.3 \pm 0.483^{\mathrm{a}}$ & $3.2 \pm 0.632^{\mathrm{a}}$ & $3.5 \pm 0.527^{\mathrm{a}}$ & $3.6 \pm 0.843^{\mathrm{a}}$
\end{tabular}

Keterangan : ${ }^{\text {a.b }}=$ notasi huruf serupa berarti tidak ada perbedaan nyata pada taraf uji Mann-Whitney pada $\alpha=0.05$

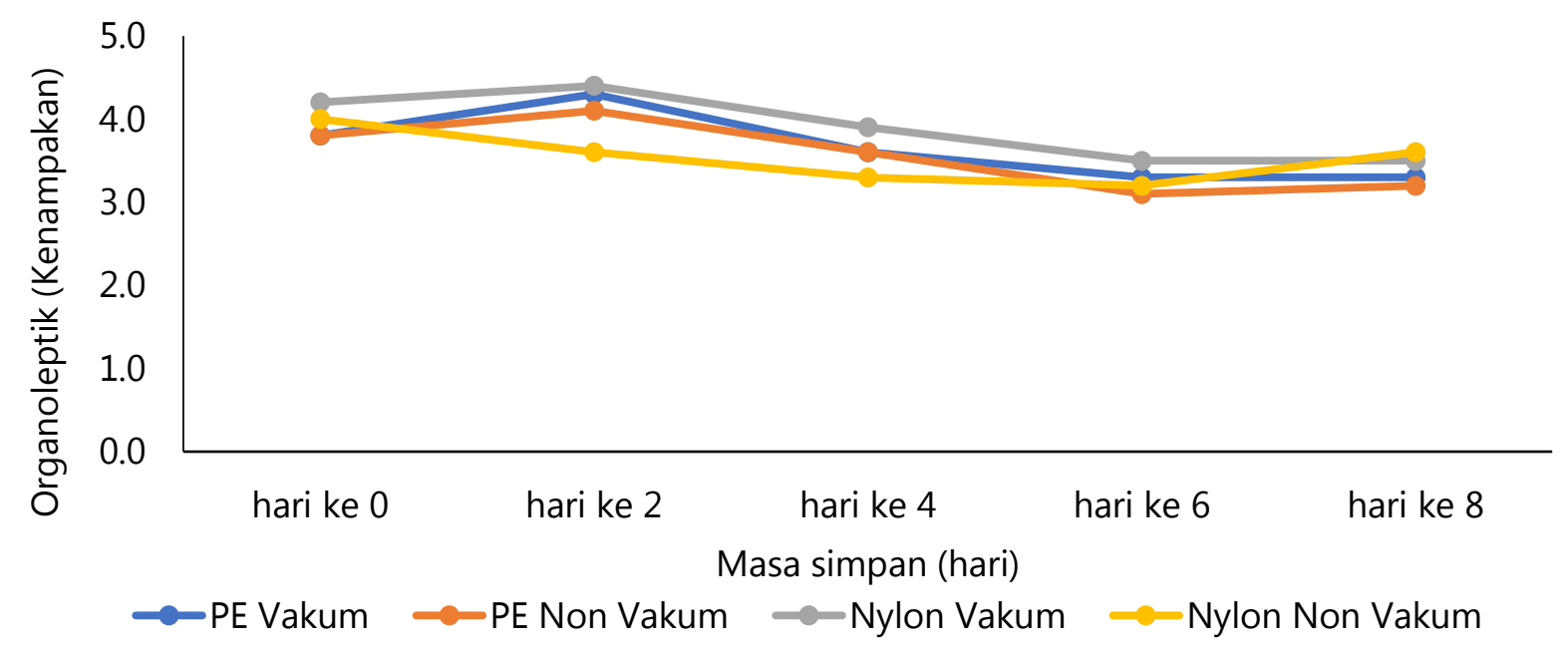

Gambar 2. Grafik masa simpan jenis kemasan terhadap Organoleptik (kenampakan) 
Tabel 3. Hasil pengujian aroma organoleptic

\begin{tabular}{lllll}
\hline \multicolumn{1}{c}{ Komponen } & \multicolumn{3}{c}{ Hasil Organoleptik (Aroma) } \\
& F1 & F2 & F3 & F4 \\
\hline Hari ke 0 & $4.4 \pm 0.516^{\mathrm{a}}$ & $4.2 \pm 0.632^{\mathrm{a}}$ & $4.3 \pm 0.675^{\mathrm{a}}$ & $4.0 \pm 0.471^{\mathrm{a}}$ \\
Hari Ke 2 & $4.3 \pm 1.059^{\mathrm{a}}$ & $4.2 \pm 1.033^{\mathrm{a}}$ & $4.1 \pm 0.738^{\mathrm{a}}$ & $4.0 \pm 0.667^{\mathrm{a}}$ \\
Hari Ke 4 & $4.3 \pm 0.483^{\mathrm{a}}$ & $4.0 \pm 0.471^{\mathrm{ab}}$ & $3.6 \pm 0.516^{\mathrm{b}}$ & $3.7 \pm 0.483^{\mathrm{b}}$ \\
Hari Ke 6 & $4.2 \pm 0.632^{\mathrm{a}}$ & $3.9 \pm 0.738^{\mathrm{a}}$ & $3.7 \pm 0.483^{\mathrm{a}}$ & $3.7 \pm 0.483^{\mathrm{a}}$ \\
Hari Ke 8 & $3.9 \pm 0.568^{\mathrm{a}}$ & $3.1 \pm 0.568^{\mathrm{b}}$ & $3.7 \pm 0.483^{\mathrm{a}}$ & $3.6 \pm 0.843^{\mathrm{ab}}$ \\
\hline
\end{tabular}

Keterangan : ${ }^{a . b}=$ notasi huruf serupa berarti tidak ada perbedaan nyata pada taraf uji Mann-Whitney pada $\alpha=0.05$

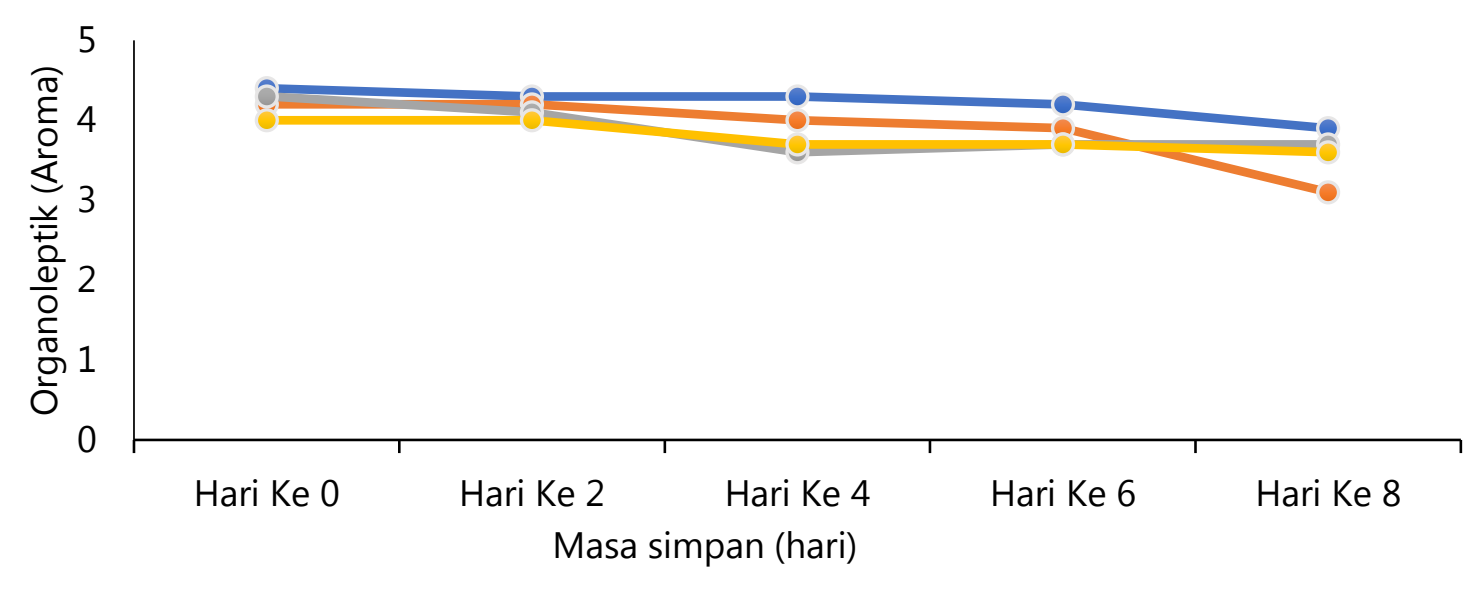

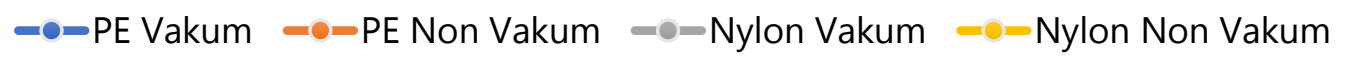

Gambar 3. Grafik masa simpan jenis kemasan terhadap organoleptik (aroma)

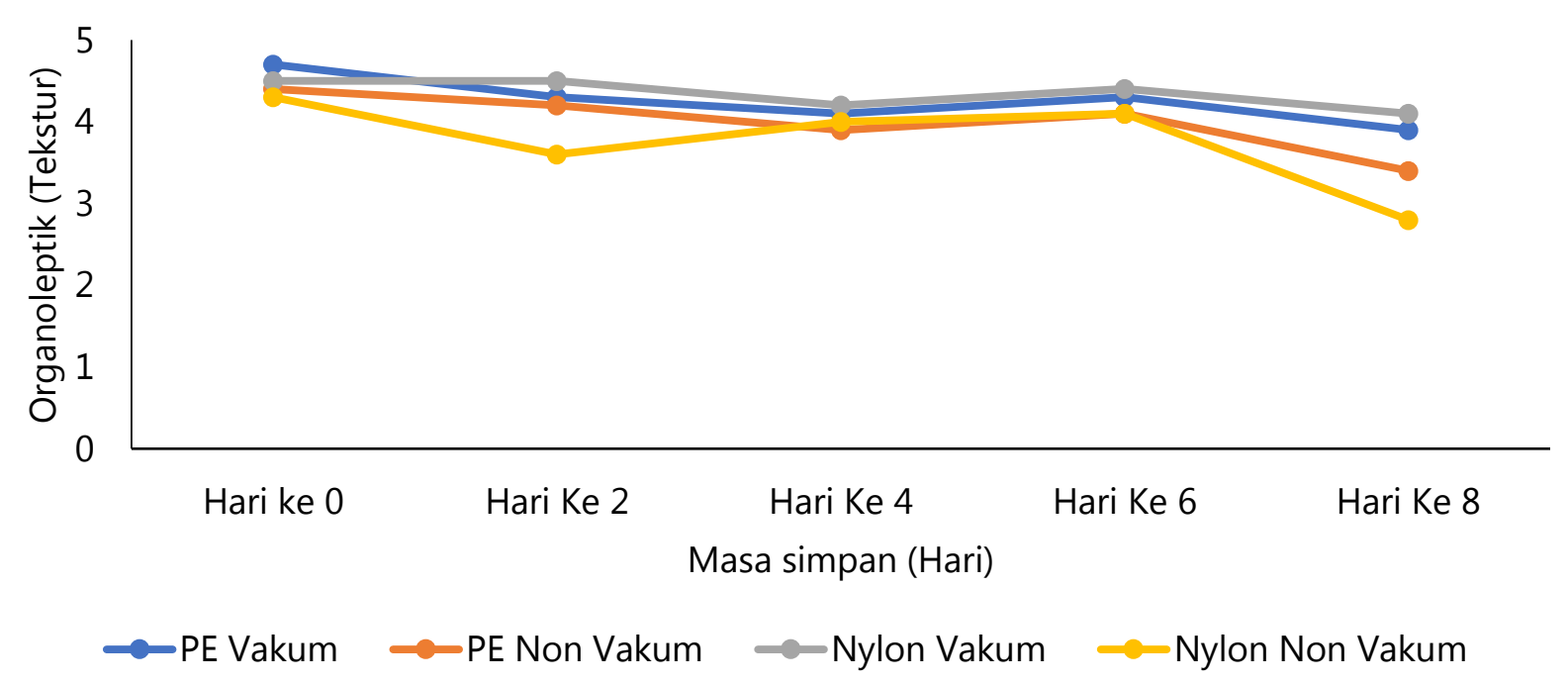

Gambar 4. Grafik masa simpan jenis kemasan terhadap organoleptik (tekstur) 
Tabel 4. Hasil pengujian Tekstur organoleptik

\begin{tabular}{lllll}
\hline \multirow{2}{*}{ Komponen } & F1 & F2 & H3 & F4 Organoleptik (Tekstur) \\
\hline Hari ke 0 & $4.7 \pm 0.483^{\mathrm{a}}$ & $4.4 \pm 0.699^{\mathrm{a}}$ & $4.5 \pm 0.527^{\mathrm{a}}$ & $4.3 \pm 0.674^{\mathrm{a}}$ \\
Hari Ke 2 & $4.3 \pm 0.675^{\mathrm{a}}$ & $4.2 \pm 0.919^{\mathrm{a}}$ & $4.5 \pm 0.850^{\mathrm{a}}$ & $3.6 \pm 1.264^{\mathrm{a}}$ \\
Hari Ke 4 & $4.1 \pm 0.568^{\mathrm{a}}$ & $3.9 \pm 0.568^{\mathrm{a}}$ & $4.2 \pm 0.422^{\mathrm{a}}$ & $4.0 \pm 0.471^{\mathrm{a}}$ \\
Hari Ke 6 & $4.3 \pm 0.675^{\mathrm{a}}$ & $4.1 \pm 0.738^{\mathrm{a}}$ & $4.4 \pm 0.699^{\mathrm{a}}$ & $4.1 \pm 0.567^{\mathrm{a}}$ \\
Hari Ke 8 & $3.9 \pm 0.568^{\mathrm{ab}}$ & $3.4 \pm 0.516^{\mathrm{ac}}$ & $4.1 \pm 0.568^{\mathrm{b}}$ & $2.8 \pm 0.918^{\mathrm{c}}$ \\
\hline
\end{tabular}

Keterangan $:{ }^{\text {a.b,c }}=$ notasi huruf serupa berarti tidak ada perbedaan nyata pada perlakuan uji Mann-Whitney pada $\alpha=0.05$

\section{KESIMPULAN}

Dari penelitian disimpulkan bahwa kadar air terendah hingga hari ke-8 adalah kemasan plastik polietilen vakum dengan nilai 2,35. Untuk pengujian Organoleptik, dapat disimpulkan dari segi kenampakan, aroma dan tekstur perlakuan yang terbaik adalah kemasan PE vakum dan Nilon vakum yang mampu meyimpan hingga hari ke-8.

\section{DAFTAR PUSTAKA}

Achmad, Furqon., Maflahah, I., Rahman, A., 2016. Pengaruh jenis pengemas dan lama penyimpanan terhadap mutu produk nugget gembus. Agrointek: Jurnal Teknologi Industri Pertanian. 10(2):71-76. DOI: 10.21107/agrointek.v10i2.2468

AOAC (2005). Official Methods of Analytical Chemistry Washington D.C. University of America.

Astuti, S.D. \& Naufalin, R. 2012. The formulation and the physicochemical and sensory characterization of analoque meatball based on oyster mushroom with the addition of euchema cotonii and cassava starch. Research Gate, June 12.

BSN [Badan Standarisasi Nasional]. 2006. SNI 01 2346-2006 petunjuk pengujian organoleptik dan atau sensori.

Candra, F.N., Riyadi, P.H. \& Wijayanti, I. 2014. Pemanfaatan karagenan (Euchema cottoni) sebagai emulsifier terhadap kestabilan bakso ikan nila (Oreochromis nilotichus) pada penyimpanan suhu dingin. Jurnal Pengolahan dan Bioteknologi Hasil Perikanan, 3(1):167176.

Hamdani, R.R., Harun, N. \& Efendi, R. 2017. Karakteristik bakso jantung pisang dan ikan patin dengan metode pengemasan vakum dan non-vakum pada suhu dingin. Jom Fakultas Pertanian, 4(2):1-14

Hendrawan, Y., Ahmad, A.M., Djoyowasito, G. \& Marantika, M.E. 2016. Pengkajian beras pecah kulit (brown rice) dalam kemasan vakum (vacuum packaging) berdasarkan ketebalan plastik kemasan jenis nilon. Jurnal Keteknikan Pertanian Tropis dan Biosistem, 4(3):250-261.

Ismail, M., Kautsar, R., Sembada, P., Aslimah, S. \& Arief, I.I. 2016. Kualitas fisik dan mikrobiologis bakso daging sapi pada penyimpanan suhu yang berbeda. Jurnal Ilmu Produksi Dan Teknologi Hasil Peternakan, 4(3):372-374.

Jayadi, A., Anwar, B. \& Sukainah, A. 2016. Pengaruh suhu penyimpanan dan jenis kemasan terhadap mutu abon ikan terbang. Jurnal Pendidikan Teknologi Pertanian, 2: 62-69.

Kartikawati, M. \& Purnomo, H. 2019. Improving meatball quality using different varieties of rice bran as natural antioxidant. Food Research, 3(1):79-85

Mulyawan, I.B., Handayani, B.R., Dipokusumo, B., Werdiningsih, W. \& Siska, A.I. 2019. Pengaruh teknik pengemasan dan jenis kemasan terhadap mutu dan daya simpan ikan pindang bumbu kuning. Jurnal Pengolahan Hasil Perikanan Indonesia, 22(3):464-475.

Maflahah, I., \& Rahman, A. 2016. Pengaruh jenis pengemas dan lama penyimpanan terhadap 
mutu produk nugget gembus. Agrointek, 10(2): 71-76.

Nofreeana, A., Masi, A. \& Deviarni, I.M. 2017. Pengaruh pengemasan vakum terhadap perubahan mikrobiologi, aktifitas air dan ph pada ikan pari asap. Jurnal Teknologi Pangan, 8(1):66-73

Nuhriawangsa, A.M.P., Budiharjo, A., Swastike, W., Hertanto, B.S., Adriyanto, B. \& Kartikasari, L.R. 2021. Physical quality of chevon meatballs with different levels of taro flour substitution as a filler. IOP Conference Series: Earth and Environmental Science, Volume 828, 3rd International Conference on Food Science and Engineering, 29-30 September 2020, Surakarta, Indonesia.

Nullah, L.N., Hafid, H. \& Indi, A. 2016. Efek bahan filler lokal terhadap kualitas fisik dan kimia bakso ayam petelur afkir. Jurnal Ilmu dan Teknologi Peternakan Tropis, 3(2): 58-63.

Nursafira, J., Munandar, A., \& Surilayani, D. 2021. Pengaruh bahan kemasan berbeda terhadap mutu bandeng presto dengan pengemasan vakum pada suhu dingin. Media Teknologi Hasil Perikanan, 9(2):59-68.

Odiase, O.M., Igene, J.O., Evivie, S.E. \& Ebabhamiegbebho, P.A. 2013. Determination and sensory evaluation of soy flour-meat combinations in the production of meatballs. Journal of Applied and Natural Science 5(2): 482-487

Park, J.H., Lee, Y.J., Lim, J.G., Jeon, J.H. \& Yoon, K.S. 2021. Effect of quinoa (chenopodium quinoa willd.) Starch and seeds on the physicochemical and textural and sensory properties of chicken meatballs during frozen storage. Foods 2021, 10(7):p1601.

Pramuditya, G., Yuwono, S, S. 2014. Penentuan atribut mutu tekstur bakso sebagai syarat tambahan dalam sni dan pengaruh lama pemanasan terhadap tesktur bakso. Penentuan Atribut Mutu Tekstur Bakso Pramuditya, dkk Jurnal Pangan dan Agroindustri, 2(4):200- 209,

Putra, A, A., Huda, N. \& Ahmad, R. 2011. Changes during the processing of duck meatballs using different fillers after the preheating and heating process. International Journal of Poultry Science 10(1):62-70,

Sujarwanta, R.O., Beya, M.M., Utami.D., Jamhari, J., Suryanto, E., Agus, A., Smyth, H.E. \& Hoffman, L.C. 2021. Rice Bran Makes a Healthy and Tasty Traditional Indonesian Goat Meatball, 'Bakso'. Foods, 10(8):p1940.

Tripariyanto, A.Y., Dewi, L., Komari, A. \& Rahayuningsih, S. 2021. Penyuluhan peningkatan produksi umkm bakso aci tata snack kediri dengan penambahan teknologi alat. Seminar Nasional Hasil Riset dan Pengabdian Ke- III (SNHRP-III 2021).

Wahyuni, N.N., Rianingsih, L. \& Romadhon 2021. Pengaruh pengemasan vakum dan nonvakum terhadap kualitas bekasam instan ikan mas (cyprinus carpio) selama penyimpanan suhu ruang. Jurnal Ilmu dan Teknologi Perikanan, 3(1):26-33. 